\title{
Iron Toxicity on Germination and Early Growth of Cecropia hololeuca Miq.
}

\section{Toxicidade por Ferro na Germinação e Crescimento Inicial de Cecropia hololeuca Miq.}

\author{
Josinei Rodrigues Filho*a, Viviana Borges Corte; Idalina Tereza de Almeida Leite Perin \\ Rodolpho Henrique Waichert da Silva ${ }^{a}$; Camila Reis ${ }^{a}$
}

aUniversidade Federal do Espírito Santo, Programa de Pós-Graduação Stricto Sensu em Biologia Vegetal. ES, Brasil. E-mail: josinei.rf@hotmail.com

\begin{abstract}
Iron $(\mathrm{Fe})$ is as an essential nutrient for plants and is irreplaceable in many metabolic processes. However, the increase in its concentration leads to the accumulation of reactive oxygen species and oxidative stress that will result in damage to plant. The objective of this work was to verify the effect of high Fe concentrations on germination and initial development of Cecropia hololeuca Miq. They were submitted to concentrations of $0.045,4$ and $8 \mathrm{mM}$ applied as ferrous sulfate and Fe-EDTA. Germination percentage, germination speed index, shoot length and root, fresh and dry mass were analyzed. For the initial developmental the following variables were analyzed: Leaf area, stem length, root length, fresh and dry mass, chloroplast pigments, chlorophyll fluorescence analysis, analysis of element contents via EDS. The activity of enzymes (SOD, CAT, POX) was verified. Both sources of Fe resulted in damage to germination and development. Fe-EDTA treatment showed the most significant negative effects on germination, root and air growth and seed biomass accumulation. The same treatment was more detrimental in the establishment of young seedlings with decreases in chlorophyll a, root growth, aerial growth, leaf area and biomass accumulation. Seedlings exposed to Fe showed a decrease in photosynthetic performance and a decrease in leaf calcium (Ca) content. No increase in CAT and SOD enzymes activity was observed. POX increased its activity when submitted to $8 \mathrm{mM}$ Fe-EDTA. These results show that the species $C$. hololeuca is sensitive when exposed to toxic levels of $\mathrm{Fe}$, causing damage to metabolism and initial growth.
\end{abstract}

Keywords: Embauba. Stress. Heavy Metal. Toxicity.

\section{Resumo}

O ferro (Fe) é um nutriente essencial para as plantas, sendo insubstituível ao metabolismo. Todavia, o aumento em sua concentração leva ao acúmulo de espécies reativas de oxigênio e estresse oxidativo que resultará em prejuízos aos vegetais. O objetivo deste trabalho foi verificar o efeito de elevadas concentrações de Fe na germinação e desenvolvimento de Cecropia hololeuca Miq. A espécie foi submetida às concentrações de 0,045, 4 e 8mM aplicados na forma de sulfato ferroso e Fe-EDTA. Foram analisadas a porcentagem de germinação, índice de velocidade de germinação, comprimento da parte aérea, radicular, massa fresca e seca. Para a análise de desenvolvimento foi analisado a área folhar o comprimento do caule, comprimento radicular, massa fresca e seca, os pigmentos cloroplastídeos, fluorescência da clorofila, e análise dos teores de elementos via EDS. Foi verificado a atividade enzimática (SOD, CAT, POX). Ambas as fontes de Fe resultaram em danos à germinação e desenvolvimento. $\mathrm{O}$ tratamento com Fe-EDTA mostrou efeitos mais significativos na germinação, crescimento aéreo e radicular e biomassa das sementes. O mesmo tratamento se mostrou mais prejudicial nas plântulas jovens com quedas na clorofila a, crescimento radicular, aéreo, área folhar e biomassa. As plântulas expostas ao Fe apresentaram queda no desempenho fotossintético e no teor de cálcio (Ca) folhar. Não foi observado aumento na atividade da CAT e SOD. A POX apresentou elevação quando submetida ao Fe-EDTA 8mM. Tais resultados evidenciam que a espécie C. hololeuca se mostra sensível a toxidez por ferro, acarretando danos ao metabolismo e crescimento inicial.

Palavras-chave: Embaúba. Estresse. Metal Pesado. Toxidez.

\section{Introduction}

Iron $(\mathrm{Fe})$ is an abundant metal in the soil and classified as an essential nutrient for plants, participating in processes such as respiration, photosynthesis, DNA, and protein synthesis (BECANA et al., 1998; JUCOSKY, 2011). Although abundant, most of the $\mathrm{Fe}$ found in the environment is in its oxidized form $\left(\mathrm{Fe}^{+3}\right)$, which is not well absorbed by plants. However, the increased concentration of Fe, emitted mainly due to the extraction and processing that generates $\mathrm{Fe}$ ore dust, combined with conditions of change in $\mathrm{pH}$ or flooding, increases the chances of absorption of metals, which will cause various damages to the plant (FAGERIA et al., 1990; JUCOSKY, 2011).
Excess $\mathrm{Fe}$ is closely linked to increased production of reactive oxygen species, culminating in the establishment of oxidative stress (NEVES et al., 2009). Also, contact with high levels of Fe causes damage to the photosynthetic apparatus, with possible loss of pigment content, fluctuations in enzymatic metabolism, chlorotic leaf spots, and drop in growth rate (AHLERT, 2010). Another worrying factor is that $\mathrm{Fe}$ does not have biodegradable characteristics and remains in the environment for long periods and causing several disturbances to rivers and riparian forests (FELIPPE et al., 2016).

Riparian forests play an important role in soil protection and compaction, as well as in the protection of terrestrial and aquatic fauna (CAMPOS et al., 2008). However, this 
ecosystem is susceptible to various environmental impacts, whether, of natural origin, such as erosion and sedimentation or of anthropic origin, such as agriculture and mining (BOTREL et al., 2002), the latter was responsible in 2015 for supplying more than 40 million cubic meters of iron-rich tailings that invaded and contaminated the riparian forests along the Rio Doce, Brazil (VIANA; COSTA, 2016).

Floristic and phytosociological studies of the riparian forests of the Rio Doce in the states of Minas Gerais and Espírito Santo indicated a great richness and diversity in the distribution of species (ALVES FERREIRA et al., 2014; CURTINHAS et al., 2015). Among the species studied, Cecropia hololeuca Miq. showed abundance and wide distribution in the area studied (ROLIM et al., 2006; CAMPOS et al., 2008; GONÇALVES et al., 2011). Cecropia hololeuca Miq. tree is commonly called embaúba and belongs to the Cecropiaceae family. It is a heliophytic species with a height between 6 and 15 meters. It is a fast-growing species, and its fruits are sought by local fauna and is always present in reforestation programs (LORENZI, 2002; CARVALHO, 2003; IPEF, 2017), thus being a species of considerable ecological importance. It is used in the manufacture of wood products (toys, pencils, phosphorus sticks), in civil construction and as a medicinal plant.

At the expense of advances in understanding the metabolic and ecophysiological responses of plants (ALTANGEREL et al., 2017; PANDEY et al., 2017), there is still little data related to specific damage to riparian vegetation caused by high levels of Fe. This work evaluated the effect of high Fe concentrations on germination and initial development of $C$. hololeuca.

\section{Material and Methods}

Seeds of C. hololeuca were harvested in 2017, in the city of Rio Doce (MG) (20¹5'16.7'S 42 53'15.6”W), and stored in a cold store chamber $\left(5^{\circ} \mathrm{C}, 15 \%\right.$ relative humidity) until the beginning of the tests, which were carried out in Laboratory of Seeds and Forest Ecophysiology of the Federal University of Espírito Santo in Vitória, ES.

The treatments were two Fe sources - ferrous sulfate and Fe-EDTA using the concentrations - $4 \mathrm{mM}$ and $8 \mathrm{mM}-$ plus a control treatment $(0,045 \mathrm{mM})$ to evaluate the seed germination and initial seedlings development

We used 100 seeds with four repetitions per treatment, and the data obtained were submitted to analysis of variance (ANOVA) and a posteriori Tukey test $(\mathrm{p} \leq 0.05)$. We performed all statistical analyses using Sisvar program (FERREIRA, 2011).

\subsection{Germination Test}

The seeds were previously disinfected with a $2 \%$ sodium hypochlorite solution for 2 minutes and sown in Petri dishes lined with two sheets of filter paper moistened with the solutions corresponding to each treatment (FERREIRA; BORGUETTI, 2005). We placed the plates in a germination chamber at a constant temperature of $25^{\circ} \mathrm{C}$ and a photoperiod of $12 \mathrm{~h}$.

The experiment monitoring was daily, considering germinated those seeds showing a radicle protrusion equal to or greater than 2mm (BRASIL, 2009). The trials ended after 14 days. The following parameters were analyzed: germination percentage $(\% \mathrm{G})$ and germination velocity index according to (MAGUIRE, 1962), aerial and radicle length (cm) (FORMAGIO et al., 2010) and fresh and dry mass (ECHER et al., 2009).

\subsection{Initial Development Analysis}

We sowed $C$. hololeuca seeds in $0.5 \mathrm{~L}$ polyethylene pots containing 1:1 unfertilized substrate and washed sand, totalizing twenty seedlings per treatment. After 20 days from germination, we submitted seedlings to the Fe treatments using Fe solutions applied via soil. The experiment was carried out in a growth room at $25^{\circ} \mathrm{C}$ and a $12 \mathrm{~h}$ photoperiod. We kept all the seedlings in the Hoagland solution at half ionic strength and pH 5.0 (HOAGLAND; ARNON, 1950).

\subsection{Growth Analysis}

The seedlings were evaluated at 10 and 20 days after the start of the treatments, using the following growth measures: leaf area, stem length, root length, fresh and dry mass.

\subsection{Extraction and quantification of chloroplastid pigments}

We determined the chlorophyll a, b, and carotenoid levels on the $20^{\text {th }}$ day after the beginning of the experiment. We used three repetitions for the analyses, each one with $20 \mathrm{mg}$ of fresh foliar mass homogenized in $5 \mathrm{~mL}$ of cold acetone (80\%). The material obtained was filtered through a funnel and filter paper, and the filtrate was stored in a $10 \mathrm{ml}$ volumetric flask, wrapped in aluminum (Al) foil and PVC. The quantification of the pigments was performed by reading the extract in a spectrophotometer at 470,645, and $662 \mathrm{~nm}$. We determined concentrations according to Lichtenthaler (1987).

\subsection{Chlorophyll fluorescence analysis}

We quantified the fluorescence of chlorophyll after 20 days of the experiment. We used fully expanded young leaves from 10 plants per treatment and previously adapted to 40 minutes of darkness by leaf clamps for complete oxidation of the photosynthetic system. The results obtained were tabulated in spreadsheets using the PEA Plus v1.11 software. From this analysis, the biophysical parameters that quantify the energy flow through the electron transport chain were calculated using the JIP test (STRASSER; STRASSER, 1995).

\subsection{Microscopic Scanning and EDS Analysis}

At the end of the experiments, seedlings were taken to 
the drying oven and dehydrated at $70{ }^{\circ} \mathrm{C}$ for three days. Later they were sectioned into leaf, stem, and root and covered with gold for analysis by scanning electron microscopy and then analyzed by EDS to detect the elements absorbed by their parts (DEDAVID et al., 2007).

\subsection{Antioxidant enzyme activities}

We verified the activity of the enzymes superoxide dismutase, peroxidase, and catalase in young seedlings at the end of the experiment. We extracted the antioxidant enzymes using $300 \mathrm{mg}$ of vegetable material homogenized with $0.1 \mathrm{M}$ potassium phosphate buffer ( $\mathrm{pH}$ 6.8), EDTANa ${ }^{2}$ $0.1 \mathrm{mM}$, and polyvinylpolypyrrolidone (PVPP) 1\% (w/v). Extractions were performed with liquid nitrogen and the homogenized centrifuged at $12000 \mathrm{xg}$ for $15 \mathrm{~min}$ at $4^{\circ} \mathrm{C}$. We used the supernatant for the superoxide dismutase (SOD), catalase (CAT), and peroxidase (POX) activities. We based the superoxide dismutase (SOD) activity on Del Longo et al. (1993), conducting the reaction at $25^{\circ} \mathrm{C}$ in a $15 \mathrm{~W}$ light bulb chamber. After 6 minutes of exposure, we did the reading at $560 \mathrm{~nm}$. The peroxidase activity (POX) was measured based on $\operatorname{Kar}(1976)$, with reaction at room temperature for 2 minutes followed by reading at $420 \mathrm{~nm}$; and the catalase activity (CAT) followed Anderson et al. (1995) protocol, performed at room temperature with reading at $240 \mathrm{~nm}$ for 2 minutes. We used three repetitions with duplicates in an entirely random design (EDS) (PEIXOTO et al., 1999).

\section{Results and Discussion}

In this study, we verified the effects of high Fe levels on $C$. hololeuca germination and initial growth. The results showed that exposure to this stress caused disturbances in seed metabolism. Although the metal did not affect germination velocity, it significantly reduced seedling shoot size in the most toxic treatment (8mM EDTA) and germination percentage, root growth, fresh and dry mass in all other treatments. The decrease in dry mass accumulation was $50 \%$ in the roots and $83 \%$ in the shoots when treated with $8 \mathrm{mM}$ Fe-EDTA, compared with the control. In the same $8 \mathrm{mM}$ treatment, it was verified an $80 \%$ fall in root size and a germination percentage of only $6 \%$, compared to $84 \%$ of control seeds (Table 1 ).

Table 1 - Effects of Fe stress on germination percentage (\% G), germination speed index (IVG), root growth (CR), shoot growth (CPA), fresh root mass (MFR), fresh mass of shoot (MFPA), dry root mass (MSR) and dry shoot mass (MSPA) of C. hololeuca seeds.

\begin{tabular}{|l|c|c|c|c|c|c|c|c|}
\hline \multicolumn{1}{|c|}{ Treatment } & \%G & IVG & CR(cm) & CPA (cm) & MFR(g) & MF PA(g) & MSR(g) & MS PA(g) \\
\hline Control & $84 \mathrm{a}$ & $1,8 \mathrm{a}$ & $0,88 \mathrm{a}$ & $0,33 \mathrm{a}$ & $0,0029 \mathrm{a}$ & $0,0039 \mathrm{a}$ & $0,0008 \mathrm{a}$ & $0,0018 \mathrm{a}$ \\
\hline Sulfate $^{+2} 4 \mathrm{mM}$ & $16 \mathrm{~b}$ & $1,5 \mathrm{a}$ & $0,72 \mathrm{~b}$ & $0,30 \mathrm{a}$ & $0,0022 \mathrm{~b}$ & $0,0032 \mathrm{ab}$ & $0,0006 \mathrm{~b}$ & $0,0010 \mathrm{ab}$ \\
\hline Sulfate $^{+2} 8 \mathrm{mM}$ & $12 \mathrm{~b}$ & $1,17 \mathrm{a}$ & $0,74 \mathrm{~b}$ & $0,35 \mathrm{a}$ & $0,0017 \mathrm{bc}$ & $0,0018 \mathrm{abc}$ & $0,0004 \mathrm{~b}$ & $0,0005 \mathrm{~b}$ \\
\hline EDTA 4mM & $14 \mathrm{~b}$ & $1,16 \mathrm{a}$ & $0,2 \mathrm{c}$ & $0,25 \mathrm{ab}$ & $0,0011 \mathrm{~cd}$ & $0,0013 \mathrm{bc}$ & $0,0004 \mathrm{~b}$ & $0,0005 \mathrm{~b}$ \\
\hline EDTA $8 \mathrm{mM}$ & 6c & $1,09 \mathrm{a}$ & $0,15 \mathrm{c}$ & $0,17 \mathrm{~b}$ & $0,0009 \mathrm{~d}$ & $0,0007 \mathrm{c}$ & $0,0004 \mathrm{~b}$ & $0,0003 \mathrm{~b}$ \\
\hline
\end{tabular}

\section{CV $(9,52 \%)$}

Different letters in the same column indicate significant difference between treatments ( $p \leq 0.05$, tukey test).

Source: Research data.

Reductions in germination potential and seedling establishment are closely related to the Fe content applied to the seeds. Although metal is essential to the germination process, even contributing to overcoming plant dormancy according to Murgia and Morandini (2017), Fe above the optimum average concentration for vegetables $(0.9 \mathrm{mM})$ is an element that can negatively affect the seed germination reported El Rasafi et al. (2016). Working with heavy metal stress, especially $\mathrm{Fe}$, on wheat and bean germination, these authors found that at the concentration of $750 \mathrm{mg} \mathrm{L}^{-1}(\sim 5 \mathrm{mM})$ of $\mathrm{Fe}$, wheat germination percentage was severely affected. We observed a significant decrease in root and aerial growth when compared to control treatment. Verma and Pandey (2017) studied the germinative behavior of seeds of the genus Vigna (Fabaceae). Their results showed that an increase in $\mathrm{Fe}$ concentration caused a decrease in germination percentage, as well as in aerial part and root growth, measured through the mass fresh and dry. We verified similar results in this study. Fe can affect the uptake and transport of water necessary for seed imbibition, which causes permanent damage to the embryo, according to Li et al. (2005) and Bautista et al. (2013). In its reduced and/or chelated form, plants absorb Fe readily. However, if in excess, it can damage membrane structures, DNA and proteins, due to the accumulation of reactive oxygen species (ROS) as reported by Nagajyoti et al. (2010).

In this study, the roots were more sensitive to $\mathrm{Fe}$ exposure than the aerial part. Similar results were found by Lingua et al. (2008) when working with species of the genus Phaseolus (Fabaceae) and Triticum (Poaceae). The fact that the root is most affected may be related to plant metabolism itself, as it is the first organ to emerge and thus come into contact with the contaminant. Also, through the deterioration of plant structural components, $\mathrm{Fe}$ stress has negative consequences on cell division and cell wall expansion, processes that are most active in primary root growth and seedling emergence (YUSUF et al., 2011). After causing morphophysiological damage, Fe toxicity then leads the plant to, according to Nenova (2006) and Mehraban et al. (2008), lose biomass, mainly by depositing in mitochondrial ridges, causing a decrease in respiratory rate and a delay in the development.

C. hololeuca seedlings exposed to toxic Fe levels after 
germination showed an increase in POX enzyme activity only in the $8 \mathrm{mM}$ Fe-EDTA treatment when compared to the control. There was no significant difference in CAT and SOD activity (Table 2).

Table 2. Effects of Fe stress on the activity of the enzymes superoxide dismutase (SOD), Total Peroxidase (POX) and catalase (CAT) in C. hololeuca seedlings

\begin{tabular}{|l|c|c|c|}
\hline \multicolumn{1}{|c|}{ Treatment } & $\begin{array}{c}\text { SOD (unid. } \\
\text { SOD g-1 } \\
\text { MS) }\end{array}$ & $\begin{array}{c}\text { CAT }(\boldsymbol{\mu m o l} \\
\text { H2O2 min-1 } \\
\mathbf{g} \text {-1 MS) }\end{array}$ & $\begin{array}{c}\text { POX }(\boldsymbol{\mu m o l} \\
\text { POX min-1 g } \\
\text {-1 MS) }\end{array}$ \\
\hline Control & $2,39 \mathrm{a}$ & $0,91 \mathrm{a}$ & $1,50 \mathrm{a}$ \\
\hline Sulfate $^{+2} 4 \mathrm{mM}$ & $2,36 \mathrm{a}$ & $1,23 \mathrm{a}$ & $1,11 \mathrm{a}$ \\
\hline Sulfate $^{+2} 8 \mathrm{mM}$ & $2,73 \mathrm{a}$ & $2,74 \mathrm{a}$ & $1,81 \mathrm{a}$ \\
\hline EDTA 4mM & $2,26 \mathrm{a}$ & $3,14 \mathrm{a}$ & $1,10 \mathrm{a}$ \\
\hline EDTA $8 \mathrm{mM}$ & $2,23 \mathrm{a}$ & $3,47 \mathrm{a}$ & $3,57 \mathrm{~b}$ \\
\hline
\end{tabular}

CV $(12,18 \%)$. Different letters in the same column indicate significant difference between treatments ( $\mathrm{p} \leq 0.05$, tukey test).

Source: Research data.

Fe is an element known for its pro-oxidative effects through the generation of several ROS and activator of the plant antioxidant system as stated by Stein et al. (2009). With the increase of ROS in cells generated by Fe accumulation, the first line of defense of the plant is the increase of SOD activity, an enzyme capable of disputing two superoxide radicals $\left(\mathrm{O}^{2-}\right)$ in molecular oxygen and hydrogen peroxide $\left(\mathrm{H}_{2} \mathrm{O}_{2}\right.$ ) (SINHA;SAXENA, 2006). The generated $\mathrm{H}_{2} \mathrm{O}_{2}$ is also toxic to the cell and must be eliminated. This process is performed by CAT and/or POXs, which act preferentially on peroxisomes and chloroplasts, respectively. Besides, POXs are related to plant growth with direct action on the cell elongation process, by transforming $\mathrm{H}_{2} \mathrm{O}_{2}$ into $\mathrm{OH}^{-}$, an important oxidizing agent in lignin formation as reported by Maia et al. (2012).

In this study, the CAT and SOD expressions were unchanged, and the POX enzyme had a significant increase only in the $8 \mathrm{mM}$ Fe-EDTA treatment. These results differ from several studies showing the positive correlation between Fe stress, increased oxidative stress in plants, and increased antioxidant enzyme activity as it was found in Pereira (2006), Jucosky (2011) and Adamski (2011). The increase in POX expression in response to $\mathrm{Fe}$ has been observed by several authors like Carli (2008) (Ipomea pes-caprae) (L.) R.Br., Kuki et al. (2008) (Schinus terebinthifolius) Raddi, and Xing et al. 2010 (Spirodela polyrrhiza) (L.) Schleid. It's elevation has been linked to a certain degree of metabolic disturbance in chloroplasts, the site of the highest activity of POX enzymes and $\mathrm{Fe}$ allocation in the leaves, being the organelle that will most quickly suffer adverse effects under stress (SPEROTTO et al., 2010).

Del Longo (1993) reported that its activity has been concurrent with several other enzymes, especially SOD and CAT. However, we did not verify this in present work, which possibly indicates a non-increase in ROS levels and oxidative stress in $C$. hololeuca seedlings, when subjected to high Fe content. Possibly, the species has its strategies to deal with oxidative damage, which can be neutralized through non-enzymatic antioxidants. This kind of process was already observed in the studies of Pekker et al. (2002) and Fourcroy et al. (2004), working with Phaseolus vulgaris L. and Arabidopsis (Brassicaceae) genus, in which treatment with glutathione, an efficient non-enzymatic antioxidant, resulted in reduced gene expression of antioxidant enzymes in seedlings exposed to high levels of Fe.

After analyzing the pigment content, a decrease in the chlorophyll content was observed in all treatments, except $\mathrm{Fe}^{+2} 4 \mathrm{mM}$, compared to the control. The levels of chlorophyll $\mathrm{b}$ and carotenoid did not change (Table 3 ).

Table 3. Effects of Fe stress on chlorophyll a, b and carotenoid concentrations of C. hololeuca seedlings

\begin{tabular}{|l|c|c|c|}
\hline \multicolumn{1}{|c|}{ Treatment } & $\begin{array}{c}\text { Chlorophylla } \\
\left(\mathbf{m g ~ g}^{-1} \mathbf{M S}\right)\end{array}$ & $\begin{array}{c}\text { Chlorophyll } b \\
\left(\mathbf{m g ~ g}^{-1} \mathbf{M S}\right)\end{array}$ & $\begin{array}{c}\text { Carotenoids } \\
\left.\text { (mg g }^{-1} \mathbf{M S}\right)\end{array}$ \\
\hline Control & $4,40 \mathrm{a}$ & $2,38 \mathrm{a}$ & $1,32 \mathrm{a}$ \\
\hline Sulfate $^{+2} 4 \mathrm{mM}$ & $5,01 \mathrm{a}$ & $2,96 \mathrm{a}$ & $1,35 \mathrm{a}$ \\
\hline Sulfate $^{+2} 8 \mathrm{mM}$ & $2,01 \mathrm{~b}$ & $2,33 \mathrm{a}$ & $1,01 \mathrm{a}$ \\
\hline EDTA 4mM & $2,15 \mathrm{~b}$ & $2,09 \mathrm{a}$ & $0,98 \mathrm{a}$ \\
\hline EDTA 8mM & $2,19 \mathrm{~b}$ & $2,89 \mathrm{a}$ & $1,21 \mathrm{a}$ \\
\hline
\end{tabular}

CV $(8,3 \%)$. Different letters in the same column indicate significant difference between treatments ( $\mathrm{p} \leq 0.05$, tukey test).

Source: Research data.

We did not observe visible chlorosis on the leaves, but it is known that $\mathrm{Fe}$ stress causes a reduction in the concentration of chloroplastic pigments through their binding to several enzymes, which causes their inactivation. Furthermore, Fe can affect the reduction of various compounds in the biosynthesis route of the pigments and has an exceptional power to inhibit protochlorophyllide reductase enzyme, which performs the conversion of protochlorophyll into chlorophyll (CHANDRA; KANG, 2016). In species of Fabaceae and some Poaceae such as rice, the accumulation of Fe caused a decrease in the concentration of chlorophyll and carotenoids which was highlighted by Mehraban et al. (2008) and Arunachalam et al. (2009). However, the chlorophyll b and carotenoid values of $C$. hololeuca seedlings were not affected by this metal, which shows that, in the species in question, Fe stress may be directed to the main route of light uptake and not to the accessory pigments. Streit et al. (2005) found, in the same pathway, that Fe through its binding power to the sulfhydryl group of proteins, can generate damage by inactivating the enzymatic mechanism responsible for the conversion of chlorophyll b (which remained unchanged) into chlorophyll a, namely, the enzyme chlorophyll a oxygenase.

We can also observe that magnesium, one of the essential elements in the formation of the chlorophyll molecule and strongly inhibited in the presence of Fe, according to Zhang et al. (2018), has not changed its concentration among the evaluated treatments (Supplementary file), which corroborates the role of $\mathrm{Fe}$ as an enzyme inhibitor in chloroplastid pigment biosynthesis. The analysis of the effects of high Fe levels 
on photosynthetic variables by the JIP test showed that the density of photosynthetic FSII reaction centers (RC/ABS) showed a significant increase only in the treatment with ferrous sulfate when compared to the control (Figure 1). There was no difference between the efficiency with which electrons move from the inter-system receptors to the final FSI receptors $(\delta \mathrm{R} 0)$ or a decrease in the performance of the FSI oxy reduction reactions $(\delta \mathrm{R} 0 /(1-\delta \mathrm{R} 0)$ or a deficiency in the FSII. However, the analysis of the total performance index (PITOTAL) shows a decrease in the overall photosynthetic performance of the plant (Figure 1).

Figure 1 - Effects of ferrous stress on RC / ABS, $\delta$ R0 $=$ RE0 / ET0, PIABS, PITOTAL and $\delta \mathrm{R} 0 /(1-\delta \mathrm{R} 0)$ of $C$. hololeuca seedlings. (C): Control (S4): $\mathrm{Fe}^{+2} 4 \mathrm{mM}$ (S8): $\mathrm{Fe}^{+2} 8 \mathrm{mM}$ (E4): FeEDTA 4mM (E8): FeEDTA 8mM. Asterisk indicates significant difference between mean and control. ( $\mathrm{p} \leq 0.05$, Tukey test).

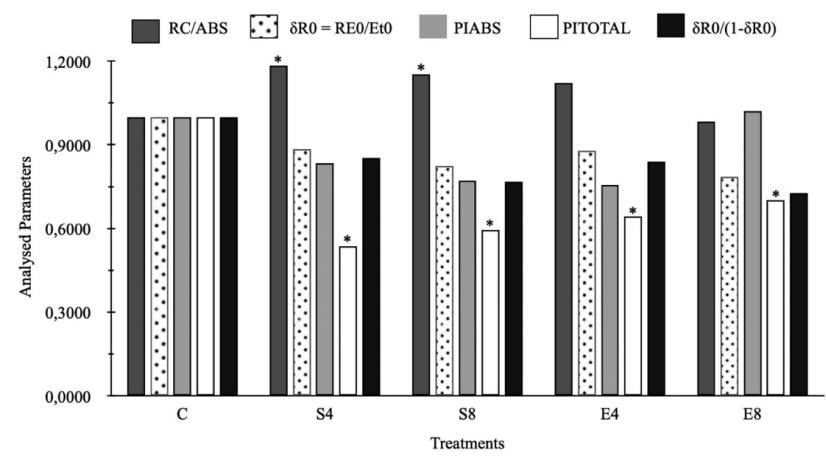

Source: Research data.

Fe is the most requested essential micronutrient in plant metabolism, acting as a co-factor in photosystems I and II, in cytochrome b6f and as a structural agent of subunits of the LHC complex. However, Pinto et al. (2016) highlights that in excess, it is known to negatively affect photosynthesis. According to Kalaji et al. (2017), among the steps in this process, the most easily affected by stress are those related to FSII due to the ease of D1 protein degeneration. RC/ABS shows the density of active FSII reaction centers, and PIABS represents all FSII activity and is commonly used as an indicator of plant vitality. $\delta \mathrm{R} 0$ and $\delta \mathrm{R} 0 /(1-\delta \mathrm{R} 0)$ represent the performance and efficiency of electrons in the oxi-reduction reactions that will culminate in the contribution of electrons to the FSII. The PITOTAL represents the total photosynthesis performance index (PSII + PSI) covering all stages of the electron transport chain and is described as the most sensitive and essential parameter of the analysis (CHEN et al., 2017).

The damage caused by high amounts of Fe has little influence on the efficiency of oxi-reduction reactions of electrons migrating to the FSI conforming to Santos Junior (2018). However, the increase in density of the FSII reaction centers (RC/ABS) in plants treated with ferrous sulfate may indicate an attempt by the plant to increase the absorption and capture of electrons in order to optimize the energy process. Galazzi (2011) and Santos Junior (2018) found similar increases in Jatropha curcas L. plants stressed by abiotic factors, especially Fe accumulation. The drop in chlorophyll a and PITOTAL content in both Fe sources, combined with results showing that FSII activity was not affected, probably reflects damage in the FSI. Araújo (2012) found similar results for the species of the genus Passiflora (Passifloraceae) exposed to Al and so did Freitas (2018) when working with Mangifera indica L., cv. Rosa, exposed to Fe. FSI is more protected from heavy metal damage than other membranous structures, indicating a lower probability of photoinhibition/oxidation than FSII. However, according to Strasser et al. (2010) and Tsimilli-Michael and Strasser (2013) the impairment of the FSI is a sign that the photochemical reactions of photosynthesis have been severely affected, which will lead to low final electron assimilation and a drop in the formation of reducing compounds, $\mathrm{NADPH}_{2}$ and ATP, also bringing damage to the carboxylation phase of photosynthesis with a consequent drop in the sugar rate and growth.

When checking the growth of seedlings submitted to high Fe levels, a visible reduction in both root size and the aerial part was observed already at ten days (Figure 2).

Figure 2 - Appearance of $C$. hololeuca seedlings 10 days after starting Fe treatment. (A): Control plant (B): $\mathrm{Fe}^{+2} 4 \mathrm{mM}(\mathrm{C}): \mathrm{Fe}^{+2} 8 \mathrm{mM}$ (D): FeEDTA 4mM (E): FeEDTA 8mM

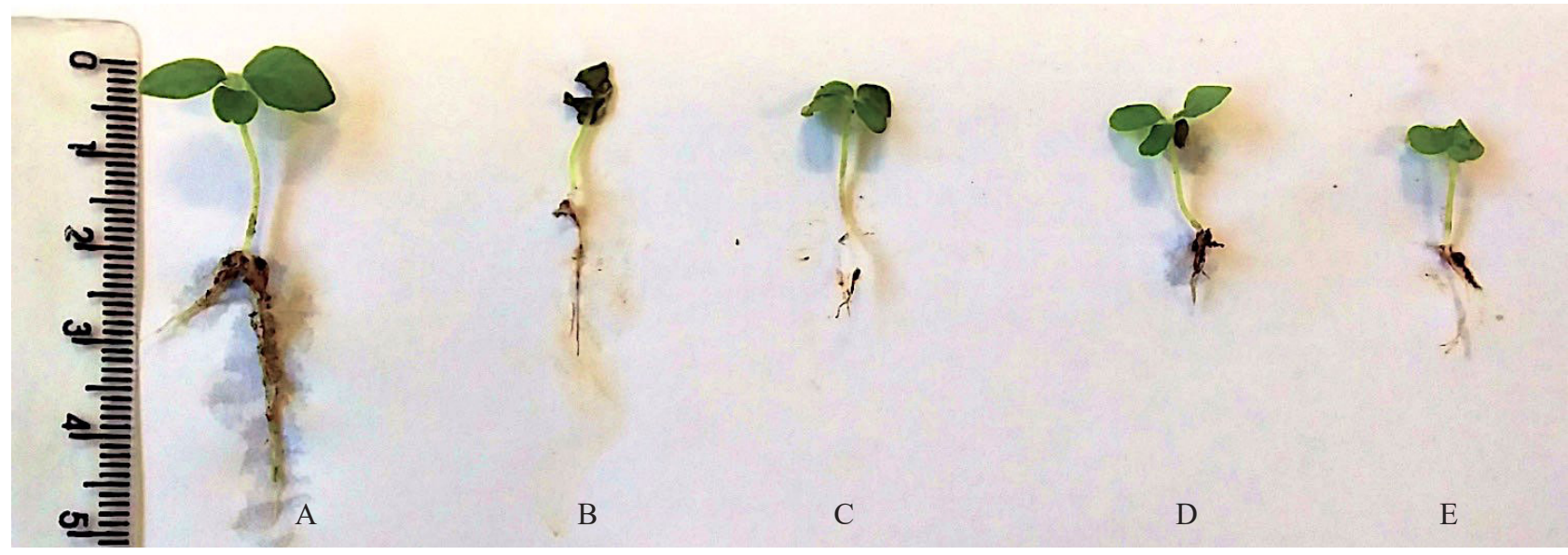

Source: Research data. 
We observed a reduction in root and stem growth, as well as in leaf area in all treatments, and Fe in its chelated form promoted the most significant damage with significant reductions in practically all variables (Table 4). We observed that treatment with Fe was dose-dependent, causing decreases of $54 \%$ in root growth, $46 \%$ in stem height, and $80 \%$ in leaf area at day 20 in the Fe-EDTA $8 \mathrm{mM}$ treatment when compared to control. The production of dry matter from the roots was compromised in the two temporal evaluations (10 and 20 days) for chelated Fe. In the aerial part, the damage was verified only at the end of the experiment for both sources of the contaminant, with Fe in the Fe-EDTA 8mM treatment causing a $75 \%$ difference in dry mass after 20 days (Table 4$)$.

Table 4 - Effects of Fe stress on root growth (Root), stem growth (Stem), leaf area (AF), fresh root mass (MFR), fresh shoot mass (MFPA), dry root mass (MSR) and shoot dry mass (MSPA) of C. hololeuca seedlings.

\begin{tabular}{|c|c|c|c|c|c|c|c|c|}
\hline \multirow{2}{*}{ Treat } & \multicolumn{2}{|c|}{ Root $(\mathrm{cm})$} & \multicolumn{2}{|c|}{ Stem $(\mathrm{cm})$} & \multicolumn{2}{|c|}{$\mathrm{AF}\left(\mathrm{cm}^{2}\right)$} & \multicolumn{2}{|c|}{$\operatorname{MFR}(\mathrm{g})$} \\
\hline & 10d. & 20d. & 10d. & 20d. & 10d. & 20d. & 10d. & 20d. \\
\hline Control & $2,64 a$ & $2,89 a$ & $1,48 \mathrm{a}$ & $2,34 a$ & $0,65 a$ & $1,73 a$ & $0,036 \mathrm{a}$ & $0,047 \mathrm{a}$ \\
\hline Sulfate $^{+2} 4 \mathrm{mM}$ & $0,99 \mathrm{~b}$ & $2,11 b$ & $1,02 b$ & $1,69 \mathrm{~b}$ & $0,42 b$ & $0,9 \mathrm{~b}$ & $0,012 b$ & $0,016 b c$ \\
\hline Sulfate $^{+2} 8 \mathrm{mM}$ & $1,08 b$ & $2,08 \mathrm{~b}$ & $1,15 \mathrm{ab}$ & $1,70 \mathrm{~b}$ & $0,24 b c$ & $0,79 b$ & $0,0048 b$ & $0,02 \mathrm{~b}$ \\
\hline EDTA $4 \mathrm{mM}$ & $0,95 \mathrm{~b}$ & $1,65 \mathrm{c}$ & $1,06 \mathrm{~b}$ & $1,36 \mathrm{c}$ & $0,26 \mathrm{bc}$ & $0,43 \mathrm{c}$ & $0,0088 b$ & $0,0090 \mathrm{~cd}$ \\
\hline EDTA $8 \mathrm{mM}$ & $0,94 b$ & $1,33 \mathrm{c}$ & $1,24 \mathrm{ab}$ & $1,28 \mathrm{c}$ & $0,21 \mathrm{c}$ & $0,35 \mathrm{c}$ & $0,0063 b$ & $0,0063 \mathrm{~d}$ \\
\hline \multirow[t]{3}{*}{ CV(10,23\%) } & & & & & & & & \\
\hline & \multicolumn{2}{|c|}{$\operatorname{MSR}(\mathrm{g})$} & \multicolumn{2}{|c|}{ MFPA (g) } & \multicolumn{2}{|c|}{ MSPA (g) } & & \\
\hline & 10d. & 20d. & 10d. & 20d. & 10d. & $20 \mathrm{~d}$. & & \\
\hline Control & $0,0049 a$ & $0,013 \mathrm{a}$ & $0,031 \mathrm{a}$ & $0,068 \mathrm{a}$ & $0,0023 \mathrm{a}$ & $0,0075 \mathrm{a}$ & & \\
\hline Sulfate $^{+2} 4 \mathrm{mM}$ & $0,0047 \mathrm{ab}$ & $0,005 b$ & $0,010 \mathrm{~b}$ & $0,051 \mathrm{~b}$ & $0,0026 \mathrm{a}$ & $0,0039 b$ & & \\
\hline Sulfate $^{+2} 8 \mathrm{mM}$ & $0,0026 \mathrm{abc}$ & $0,0028 \mathrm{c}$ & $0,010 \mathrm{~b}$ & $0,040 \mathrm{~b}$ & $0,0030 \mathrm{a}$ & $0,0038 b$ & & \\
\hline EDTA $4 \mathrm{mM}$ & $0,0024 b c$ & $0,0025 \mathrm{c}$ & $0,007 \mathrm{~b}$ & $0,020 \mathrm{c}$ & $0,0022 \mathrm{a}$ & $0,0026 \mathrm{c}$ & & \\
\hline EDTA $8 \mathrm{mM}$ & $0,0021 \mathrm{c}$ & $0,0022 \mathrm{c}$ & $0,0062 b$ & $0,016 \mathrm{c}$ & $0,0018 \mathrm{a}$ & $0,0019 \mathrm{c}$ & & \\
\hline $\mathrm{CV}(10,23 \%)$ & & & & & & & & \\
\hline
\end{tabular}

Different letters in the same column indicate significant difference between treatments ( $\mathrm{p} \leq 0.05$, tukey test).

Source: Research data.

Several studies have highlighted the harmful effect of Fe stress on plant growth. Jucoski (2011) working with the accumulation of different $\mathrm{Fe}$ concentrations under the growth of Eugenia uniflora L., noticed a great decrease in leaf number, root size, and biomass allocation. Adamski (2011), when submitting Ipomoea batatas (L.) Lam plants to concentrations of 4 and $9 \mathrm{mmol}$ of $\mathrm{Fe}$, observed a decrease in the length of branches, leaf area, dry mass, and the number of roots of the specimens. Other results include a decrease in plant height, accompanied by a drop in productivity and ultimately plant death as described by Schmidt et al. (2013). We can correlate Fe with the decrease in growth rate, at first, by the damage caused to the biochemical metabolism due to the accumulation of oxidizing substances. However, other pronounced effects include disturbances in nitrogen and carbohydrate metabolism, changes in plasma membrane fluidity with consequent lipid peroxidation, protein inactivation in the membrane itself and damage to the structure of several cytoplasmic organelles, especially the mitochondria, which will culminate in cell overflow (RODRIGUES et al., 2016).

We found, as for the assimilation of elements, that the roots had different concentrations of assimilated Fe. The treatment with $\mathrm{Fe}^{+2} 4 \mathrm{mM}$ was the one that achieved the highest percentage of accumulation (11.91\%), whereas Fe-EDTA 4mM had an accumulation of $5.56 \%$. Also, we observed that, with the increase in Fe concentration of both sources used, there was a decrease in root accumulation, with $\mathrm{Fe}^{+2} 8 \mathrm{mM}$ composing
$7.96 \%$ of the weight in the root and Fe-EDTA $8 \mathrm{mM}$ only $1.18 \%$, indicating a tendency of $\mathrm{Fe}$ allocation in the aerial part when it reaches high concentrations (Supplementary File). In plants, the distribution of macro and micronutrients depends basically on transport via xylem and phloem. As studied by Stein et al. (2009) and Morrissey and Guerinot (2009) due to Fe low mobility, it encounters limitations for translocation to the aerial part (about 14\%), and roots retain it extensively, with almost $75 \%$ of its content linked to the apoplast. Thus, with Fe saturation in the roots, its transport to the leaves would be deficient due to the rapid binding to chelating compounds, mainly ferritin, reducing its activity (DOS SANTOS et al., 2011). However, in this study, there was an increase in Fe transport from the root at concentrations of $8 \mathrm{mM}$. This result is in agreement with Tripathi et al. (2018), who in their study, noticed that in very high concentrations of $\mathrm{Fe}(8 \mathrm{mM})$, the plant presents the strategy of translocating the metal to the aerial part, especially the young leaves, which would balance the toxicity, not concentrating only on the root, primary target of stress.

Plants treated with $\mathrm{Fe}$ in its chelated form showed a $40 \%$ reduction in foliar calcium content (Supplementary File). $\mathrm{Fe}$ in high doses is known as a potent unbalancing agent of the metabolism of various elements, especially magnesium, phosphorus, potassium, and $\mathrm{Ca}$ conforming to Tanaka et al. (1966) and Zhang et al. (2018). Along the evolutionary course, plants developed several strategies to balance the 
entrance of $\mathrm{Fe}$ in their tissues, avoiding competition with other ions. Following Morrissey and Guerinot (2009), the main mechanisms are related to the modification of the environment around the root epidermis, via acidification of the habitat by releasing protons, which will allow differences in the solubility of the element. Another strategy adopted is morpho-anatomic changes, mainly in leaves and roots by ensuring an adaptation to prevent damage caused by the absorption of high levels of Fe. The element will still be present in the soil, but almost exclusively in its oxidized and not assimilable form. The oxidation of Fe will initiate the formation of Fe plates that can, even if indirectly, harm plant growth. According to Liu et al. (2007), because the plate presents physical-chemical characteristics similar to the $\mathrm{Fe}$ oxides found in the environment, which can affect the absorption of other elements through adsorption or coprecipitation so that it may explain the decrease in the foliar $\mathrm{Ca}$ rate and consequently a decrease in growth. Muller et al. (2015) found similar results in other plants when submitted to different forms of Fe.

\section{Conclusion}

Fe in concentrations of $4 \mathrm{mM}$ and $8 \mathrm{mM}$ affects the germination process of $C$. hololeuca seeds, generating a drop in the percentage of germination, growth, and accumulation of biomass. The activity of the enzymes SOD and CAT was not sensitive to Fe toxicity, whereas only POX had its expression increased in $C$. hololeuca seedlings when exposed to $8 \mathrm{mM}$ concentration, which does not show significant oxidative stress.

Concentrations of $4 \mathrm{mM}$ and $8 \mathrm{mM}$ affect the initial development at $10^{\text {th }}$ and $20^{\text {th }}$ days evaluations, with a drop in root and aerial growth, leaf area, and biomass accumulation. $\mathrm{Fe}$ can negatively affect the chlorophyll a content, and the photosynthesis of $C$. hololeuca presented significant damage to the PSI, as well as a drop in the general performance of the plant. Fe in high concentrations presents allocation capacity in different parts of the seedling, and in its chelated form, showed interference in Ca metabolism.

\section{References}

ADAMSKI, J. M. Respostas morfológicas de Ipomoea batatas L. em função da concentração de ferro. 2011. Pelotas: Universidade Federal de Pelotas, Pelotas, 2011.

AHLERT, R. J. Análise proteômica diferencial em raízes de plântulas de arroz (Oriza sativa L.) submetidas ao estresse por ferro. Pelotas: Universidade Federal de Pelotas, 2010.

ALTANGEREL, N. et al. In vivo diagnostics of early abiotic plant stress response via Raman spectroscopy. Proc. Natl. Acad. Sci., v.114, n.13, p.3393-3396, 2017. doi: 10.1073/pnas.1701328114.

ALVES FERREIRA, E. et al. Levantamento fitossociológico de plantas daninhas em pastagens degradadas do Médio Vale do Rio Doce, Minas Gerais. Rev. Ceres, v.61, n.4, p.502-510, 2014. doi: 10.1590/0034-737X201461040008.

ANDERSON, M. D; PRASAD, T. K.; STEWART, C. R. Changes in isozyme profiles of catalase, peroxidase, and glutathione reductase during acclimation to chilling in mesocotyls of maize seedlings. Plant Physiol., v.109, p.1247-1257, 1995. doi: 10.1104/ pp.109.4.1247.

ARAUJO, R. A. Estresse por alumínio alterações ecofisiologicas e bioquimicas em variedades do maracujazeiro. Vitória: Universidade Federal do Espírito Santo, 2012.

ARUNACHALAM, R. et al. Environmental assessment due to air pollution near iron smelting industry. J. Environ. Sci. Technol., v. 2, p. 179-186, 2009. doi: 10.3923/jest.2009.179.186.

BAUTISTA, O. V.; FISCHER, G.; CÁRDENAS, J. F. Cadmium and chromium effects on seed germination and root elongation in lettuce, spinach and Swiss chard. Agron. Colomb, v. 31, n. 1, p. 48-57, 2013.

BECANA, M.; MORAN, J. F.; ITURBE-ORMAETXE, I. Iron dependent oxygen freeradical generation in plants subjected to environmental stress: toxicity andantioxidant protection. Plant Soil, v. 201, n. 1, p. 137-147, 1998.

BOTREL, R. T. et al. Influência do solo e topografia sobre as variações da composição florística e estrutura da comunidade arbóreo-arbustiva de uma floresta estacional semidecidual em Ingaí, MG. Rev. Bras. Bot., v.25, p.195-213, 2002. doi: 10.1590/ S0100-84042002000200008.

BRASIL. Ministério da Agricultura, Pecuária e Abastecimento. Regras para análise de sementes. Brasília: Mapa 2009.

CAMPOS, A. C. A. L. et al. Levantamento florístico e fitossociológico da mata ciliar do Rio das Mortes em São João del-Rei, Minas Gerais. Rev. Bras. Bio.., v.5, n.2, p.1177-1179, 2008.

CARLI, V. G. Avaliações fisiológicas, Bioquímicas e Histoquímica de Ipomoae pés-caprae cultivada em diferentes concentrações de ferro. Viçosa: Universidade Federal de Viçosa, 2008.

CARVALHO, P.E.R. Espécies arbóreas brasileiras. Brasília: Embrapa, 2003.

CHANDRA, R.; KANG, H. Mixed heavy metal stress on photosynthesis, transpiration rate, and chlorophyll content in poplar hybrids. Forest Scie. Technol., v.12, n.2, p.55-61, 2016. doi: 10.1080/21580103.2015.1044024.

CHEN, S. et al. Classification and characteristics of heat tolerance in Ageratinaadenophora populations using fast chlorophyll a fluorescence rise OJIP. Environ. Exp. Bot., v. 122, p. 126-140, 2017. doi: 10.1016/j.envexpbot.2015.09.011.

CURTINHAS, J. N. et al. Caracterização fitossociológica da vegetação herbácea de áreas alteradas pela atividade agropecuária na região do Médio Vale do Rio Doce, Minas Gerais. Rev. Ceres, v.57, n.3, p.321-329, 2015. doi: 10.1590/ S0034-737X2010000300006.

DEDAVID, B. A.; GOMES, C. I.; MACHADO, G. Microscopia eletrônica de varredura: aplicações e preparação de amostras: materiais poliméricos, metálicos e semicondutores. Porto Alegre: EdiPUCRS, 2007.

DEL LONGO, O. T. et al. Antioxidant defenses under hyperoxygenic and hyperosmotic conditions in leaves of two lines of maize with differential to drought. Plant Cell Physiol., v.37, n.7, p.1023-1028, 1993. doi: 10.1093/oxfordjournals.pcp. a078515.

DOS SANTOS, F. S. et al. Resposta antioxidante, formação de fitoquelatinas e composição de pigmentos fotoprotetores em BrachiariadecumbensStapf submetida à contaminação com Cd e Zn. Quim. Nova, v. 34, n. 1, p. 16-20, 2011. doi: 10.1590/S010040422011000100004. 
ECHER, F. R.; DOMINATO, J. C.; CRESTE, J. E. Absorção de nutrientes e distribuição da massa fresca e seca entre órgãos de batata-doce. Hortic. bras., v.27, n.2, p.176-182, 2009. doi: 10.1590/S0102-05362009000200010.

EL RASAFI, T. et al. The effect of $\mathrm{Cd}, \mathrm{Zn}$ and $\mathrm{Fe}$ on seed germination and early seedling growth of wheat and bean. Ekológia (Bratisl), v.35, n.3, p.213-223, 2016. doi: 10.1515/eko2016-0017.

FAGERIA, N.K.; BALIGAR, V.C; WRIGHT, R.J. Iron nutrition of plants: an overview on the chemistry and physiology of its deficiency and toxicity. Pesq. Agropec. Bras., v.25, p.553-570, 1990

FELIPPE, M. F. et al. A tragédia do Rio Doce: A lama, o povo e a água. Relatório de Campo e Interpretações preliminares Sobre as Consequências do Rompimento da Barragem de Rejeitos de Fundão (Samarco/Vale/Bhp). Rev. Geografias, p.63-94, 2016. doi: 10.13140/RG.2.1.2677.0960.

FERREIRA, A.G.; BORGHETTI, F. Germinação: do básico ao aplicado. Porto Alegre: Artmed, 2005.

FERREIRA, D.F. Sisvar: a computer statistical analysis system. Ciênc. Agrotec., v.35, n.6, p.1039-1042, 2011.

FORMAGIO, A. S. N. et al. Potencial alelopático de cinco espécies da família Annonaceae. Rev. Bras. Bioc., v. 8, n. 4, p.349-354, 2010.

FOURCROY, P. et al. Iron-regulated expression of a cytosolic ascorbate peroxidase encoded by the APX1 gene in Arabidopsis. Plant Physiol, v.134, p.1-9. 2004. doi: 10.1104/pp.103.029876.

FREITAS, J.F.N. Crescimento inicial e eficiência fotoquímica de mangueiras cultivadas em solo contendo lama do rio doce. Vitória: Universidade Federal do Espírito Santo, 2018.

GALAZZI, E.B. Desempenho fotossintético de plantas de Jatropha curcas L. cultivadas no estado do Espírito Santo. Vitória: Universidade Federal do Espírito Santo, 2011.

GONÇALVES, I. D. S. et al. Fatores edáficos e as variações florísticas de um trecho de mata ciliar do Rio Gualaxo do Norte, Mariana, MG. Rev. Árvore, v. 35, n. 6, p. 1235-1243,2011. doi: $10.1590 /$ S0100-67622011000700010.

HOAGLAND, D. R.; ARNON, D.I. The water-culture method for growing plants without soil. Circular. California Agricul.l Experiment Station, v. 347, n. 2, 1950.

IPEF - Instituto de Pesquisas e Estudos Florestais. Identificação de espécies florestais. Disponível em: $<$ https://www.ipef.br $/>$. Acesso em: 7 abr. 2020

JUCOSKI, G. O. Toxicidade de ferro e metabolismo antioxidativo em Eugenia uniflora L. Viçosa: Universidade Federal de Viçosa, 2011.

KALAJI, H.M. et al. Chlorophyll a fluorescence as a tool to monitor physiological status of plants under abiotic stress conditions. Photosynth. Res., v.132, p.13-66, 2017. doi: 10.1007/ s11738-016-2113-y.

KAR, M.; MISHRA, D. Catalase, peroxidase, and polyphenoloxidase activities during rice leaf senescence. Plant Physiol., v.57, p.315-319, 1976. doi: 10.1104/pp.57.2.315.

KUKI, K. N. et al. Effects of simulated deposition of acid mist and iron ore particulate matter on photosynthesis and the generation of oxidative stress in Schinus terebinthifolius Radii and Sophora tomentosa L. Sci. Total Environ., v.403, p.207-214, 2008. doi: 10.1016/j.scitotenv.2008.05.004.

LI, W. et al. Effects of heavy metals on seed germination and early seedling growth of Arabidopsis thaliana. Plant Growth
Regul., v.46, p. 45-50, 2005. doi: 10.1007/s10725-005-6324-2.

LINGUA, G. et al. Arbuscular mycorrhizal fungi differentially affect the response to high zinc concentrations of two registered poplar clones. Environ. Pollut., v.153, p.137-147, 2008. doi: 10.1016/j.envpol.2007.07.012.

LICHTHENTALER, H.K. Chlorophyll and carotenoids-pigments of photosynthetic biomembranes. Method Enzymol, v, 148, p. 350-382, 1987. doi: 10.1016/0076-6879(87)48036-1.

LIU, H. J.; ZHANG, J.L.; ZHANG, F.S. Role of iron plaque in Cd uptake by and translocation within rice (Oryza sativa L.) seedlings grown in solution culture. Environ Exp Bot, v.59, p.314-320, 2007. doi: 10.1016/j.envexpbot.2006.04.001.

LORENZI, H. Árvores brasileiras: manual de identificação e cultivo de plantas arbóreas do Brasil. Nova Odessa: Instituto Plantarum, 2002.

MAGUIRE J. D. Speed of germination-aid in selection and evaluation for seedling emergence and vigor. Crop $S c i$, v.2, n.1, p.176-177, 1962. doi: 10.2135/cropsci1962.0011183X00020002 $0033 x$.

MAIA, J. M. et al. Atividade de enzimas antioxidantes e inibição do crescimento radicular de feijão caupi sob diferentes níveis de salinidade. Acta Bot. Bras., v.26, n.2, p.342-349, 2012. doi: 10.1590/S0102-33062012000200010.

MEHRABAN, P.; ZADEH, A. A.; SADEGHIPOUR, H. R. Iron toxicity in rice (Oryza sativa L.), under different potassium nutrition, Asian J. Plant Sci., v.7, p.251-259, 2008. doi: 10.3923/ ajps.2008.251.259.

MORRISSEY, J.; GUERINOT, M. L. Iron uptake and transport in plants: the good, the bad, and the ionome. Chem. Rev., v. 109, n. 10, p. 4553-4567, 2009. doi: 10.1021/cr900112r.

MÜLLER, C. et al. Differential physiological responses in rice upon exposure to excess distinct iron forms. Plant Soil, v.391, p.123-138,2015. doi: 10.1007/s11104-015-2405-9.

MURGIA, I.; MORANDINI, P. Iron deficiency prolongs seed dormancy in Arabidopsis plants. Front Plant Sci, v. 8, p. 1-5, 2017. doi: 10.3389/fpls.2017.02077.

NAGAJYOTI, P.C.; LEE, K.D.; SREEKANTH T.V.M. Heavy metals, occurrence and toxicity for plants: a review. Environ. Chem. Lett., v. 8, p. 199-216, 2010. doi: 10.1007/s10311-0100297-8.

NENOVA, V. Effect of iron supply on growth and photosystem II efficiency of pea plants. Gen.Appl. Plant Physiol. v.32, p. 81-90, 2006.

NEVES, N.R. et al. Photosynthesis and oxidative stress in the restinga plant species Eugenia uniflora L. exposed to simulated acid rain and iron ore dust deposition: Potential use in environmental risk assessment. Sci. Total Environ., v.407, p.3740-3745, 2009. doi: 10.1016/j.scitotenv.2009.02.035.

PANDEY, N. et al. Phytohormones and Drought Stress: Plant Responses to Transcriptional Regulation. Mechanism of Plant Hormone Signaling under Stress, v. 2, p. 477-504, 2017. doi: 10.1002/9781118889022.ch34.

PEIXOTO, P.H.P. et al. Aluminum effects on lipid peroxidation and on the activities of enzymes of oxidative metabolism in sorghum. Rev. Bras. Fisiol. Veg.,v. 11, p.137-143, 1999.

PEKKER, I.; TEL-OR, E.; MITTLER, R.Reactive oxygen intermediates and gluta- thione regulate the expression of cytosolic ascorbate peroxidase during iron- mediated oxidative stress in bean. Plant Mol. Biol., v. 49, p. 429-438, 2002. doi: 10.1023/a:1015554616358. 
PEREIRA, E. G. Efeitos fisiológicos e bioquímicos causados pela deposição de ferro particulado em Clusia hilariana, uma espécie de restinga. Viçosa: Universidade Federal de Viçosa, 2006.

PINTO, S. D. S. et al. Oxidative damage and photosynthetic impairment in tropical rice cultivars upon exposure to excess iron. Sci. Agric., v.73, n.3, p.217-226, 2016. doi: 10.1590/01039016-2015-0288.

RODRIGUES, A. C. D. et al. Mecanismos de respostas das plantas à poluição por metais pesados: possibilidade de uso de macrófitas para remediação de ambientes aquáticos contaminados. Rev. Virtual Quim., v.8, n.1, p.262-276, 2016. doi: 10.5935/19846835.20160017 .

ROLIM, S. G. et al. Composição florística do estrato arbóreo da floresta estacional semidecidual na planície aluvial do rio Doce, Linhares, ES, Brasil. Acta Bot. Bras, v.20, n.3, p.549-561, 2006. doi: 10.1590/S0102-33062006000300005.

SANTOS JUNIOR, R. N. Fisiologia de Acessos de Jatropha Curcas L. Cultivados em Solo Contendo Lama do Rio Doce. Vitória: Universidade Federal do Espírito Santo, 2018

SCHMIDT, F. et al. Impacto do manejo da água na toxidez por ferro no arroz irrigado por alagamento. Rev. Bras. Ciênc. Solo, v.37, n.5, p.1226-1235, 2013. doi: 10.1590/S010006832013000500012 .

SINHA, S.; SAXENA, R. Effect of iron on lipid peroxidation, and enzymatic and non-enzymatic antioxidants and bacoside-A content in medicinal plant Bacopa monnieri L. Chemosphere, v.62, p.1340-1350, 2006. doi: 10.1016/j.chemosphere.2005.07.030.

SPEROTTO, R. A. et al. Iron stress in plants: dealing with deprivation and overload. Plant Stress, v. 4, p.57-69, 2010.

STEIN, R.R.J. et al. Distinct physiological responses subjected to iron toxicity under field conditions. Ann. Appl. Biol., v. 154, p. 269-277, 2009. doi: 10.1111/j.1744-7348.2008.00293.x.

STRASSER, B. J.; STRASSER, R. J. Measuring fast fluorescence transients to address environmental questions: The JIP-test. In: MATHIS, P. (Ed.) Photosynthesis: from 74 Light to Biosphere., Dordrecht:Kluwer Academic Publishers.Netherlands, 1995. p. 977-980.
STRASSER, R. J. et al. Simultaneous in vivo recording of prompt and delayed fluorescence and $820 \mathrm{~nm}$ reflection changes during drying and after rehydration of the resurrection plant Haberlea rhodopensis. Biochim. Biophys. Acta (BBA), v. 1797, n. 6-7, p. 1313-1326, 2010. doi: 10.1016/j.bbabio.2010.03.008.

STREIT, N. M. et al. As clorofilas. Ciênc. Rural, v.35, n.3, p.748755, 2005. doi: 10.1590/S0103-84782005000300043.

TANAKA, A.; LOE, R.; NAVASERO, S. A. Some mechanisms involved in the development of iron toxicity symptoms in the rice plant. Soil Sci. Plant Nutr, v.12, p.32-38, 1966. doi: 10.1080/00380768.1966.10431951.

TRIPATHI, D. K. et al. Acquisition and homeostasis of iron in higher plants and their probable role in abiotic stress tolerance. Front Env Sci Eng, v.5, p.86, 2018. doi: 10.3389/ fenvs.2017.00086.

TSIMILLI-MICHAEL, M.; STRASSER, R. J. The energy flux theory 35 years later: formulations and applications. Photosynth. Res., v. 117, p.289- 320, 2013. doi: 10.1007/s11120-013-9895-1.

VERMA, L.; PANDEY, N. The Effect of Iron Toxicity on Seed Germinationand Early Seedling Growth of Green Gram (Vigna radiata L. Wilczek). Int. J. Sci. Res., v.6, n.8, 2017.

VIANA, J. H. M.; COSTA, A. M. A ciência do solo como instrumento para a recuperação das áreas afetadas pelo desastre de Mariana e dos solos na Bacia do Rio Doce. Embrapa Milho e Sorgo. Bol.Inform. Soc. Bras. Ciênc. Solo, v.42, n.1, p.24-27, 2016.

XING, W.; LI, D.; LIU, G. Antioxidative responses of Elodea nuttallii (Planch.) H. St. John to short-term iron exposure. Plant Physiol. Biochem., v.48, p.873-878,2010. doi: 10.1016/j. plaphy.2010.08.006.

YUSUF, M.et al. A. Nickel: an overview of uptake, essentiality and toxicity in plants. Bull. Environ. Contam. Toxicol., v. 86, p. 1-17, 2011. doi: 10.1007/s00128-010-0171-1.

ZHANG, L. et al. Excess iron stress reduces root tip zone growth through nitric oxide-mediated repression of potassium homeostasis in Arabidopsis. New Phytol., v. 219, n.1, p. 259-274, 2018. doi: 10.1111/nph.15157. 